\title{
Homologous and heterologous down-regulation of leptin receptor messenger ribonucleic acid in rat adrenal gland
}

\author{
M Tena-Sempere, L Pinilla, L C González, F F Casanueva² \\ C Diéguez ${ }^{1}$ and $\mathbf{E}$ Aguilar
}

Department of Physiology, University of Córdoba, 14004 Córdoba, Spain

${ }^{1}$ Department of Physiology, University of Santiago de Compostela, 15705 Santiago de Compostela, Spain

${ }^{2}$ Department of Medicine, University of Santiago de Compostela, 15705 Santiago de Compostela, Spain

(Requests for offprints should be addressed to M Tena-Sempere, Department of Physiology, Faculty of Medicine, University of Córdoba, Avda Menéndez Pidal s/n, 14004 Córdoba, Spain; Email: fi1tesem@uco.es)

\begin{abstract}
Leptin, the adipocyte-produced hormone that plays a key role in body weight homeostasis, has recently been found to be involved in the regulation of the hypothalamicpituitary-adrenal axis. Moreover, reciprocal interactions between leptin and glucocorticoids have been described. In the present communication, two different strategies were undertaken to explore the mode of action of leptin in the direct control of rat adrenal function. First, a synthetic peptide approach demonstrated that the inhibitory effect of leptin on basal and ACTH-stimulated corticosterone secretion in vitro is, at least partially, mapped to a domain of the native protein between amino acids 116 and 130, i.e. an area of the molecule also relevant in terms of regulation of food intake and endocrine control. Secondly, semi-quantitative RT-PCR analysis indicated a complex pattern of adrenal leptin receptor (Ob-R) mRNA expression, with predominant expression of the Ob-Ra and $\mathrm{Ob}-\mathrm{Rb}$ isoforms, as well as moderate levels of the $\mathrm{Ob}-\mathrm{Rc}$
\end{abstract}

and $\mathrm{Ob}-\mathrm{Rf}$ variants, whereas negligible signals for the $\mathrm{Ob}-\mathrm{Re}$ isoform were detected. Interestingly, such an expression pattern appeared hormonally regulated as exposure to human recombinant leptin $\left(10^{-7} \mathrm{M}\right)$ or ACTH $\left(10^{-7} \mathrm{M}\right)$ significantly decreased Ob-R isoform mRNA expression. Indeed, dose-dependent ligandinduced $\mathrm{Ob}-\mathrm{Ra}$ and $\mathrm{Ob}-\mathrm{Rb}$ mRNA down-regulation was further confirmed by adrenal stimulation with increasing concentrations $\left(10^{-9}-10^{-5} \mathrm{M}\right)$ of the active leptin fragment, leptin 116-130 amide. Overall, our results provide evidence for a novel regulatory step at the level of $\mathrm{Ob}-\mathrm{R}$ mRNA expression in the interplay between ACTH and leptin for the tuning of rat adrenal corticosterone secretion. Furthermore, our data showing downregulation of $\mathrm{Ob}-\mathrm{R}$ mRNA expression by its cognate ligand may well be relevant to leptin physiology and its alteration in various disease states.

Journal of Endocrinology (2000) 167, 479-486

\section{Introduction}

Leptin, the product of the $o b$ gene, is an adipocyte-secreted plasma hormone that plays a pivotal role in body weight homeostasis, neuroendocrine function and fertility (Friedman \& Halaas 1998, Rosenbaum \& Liebel 1998). Recently, leptin has emerged as a key element in the regulation of the hypothalamic-pituitary-adrenal (HPA) axis (Casanueva \& Dieguez 1999). However, the mechanisms by which leptin acts upon the HPA system remain controversial; a direct effect of leptin in the regulation of adrenal function has been reported, yet both stimulatory and inhibitory responses have been described (Bornstein et al. 1997, Malendowicz et al. 1997, Pralong et al. 1998).

The biological actions of leptin on target tissues are carried out through interaction with its specific receptor, $\mathrm{Ob}-\mathrm{R}$. A hallmark of $\mathrm{Ob}-\mathrm{R}$ gene expression is the presence of several receptor variants (Ob-Ra to $\mathrm{Ob}-\mathrm{Rf}$ ) that are generated by alternative splicing; they share the extracellular domain but differ in the length of the transmembrane/cytoplasmic coding regions (Tartaglia et al. 1995, Lee et al. 1996, Takaya et al. 1996, Tartaglia 1997). The long Ob-Rb subtype appears as the functional, signal-transducing isoform responsible for the hypothalamic actions of leptin (Tartaglia 1997). The roles of the shorter $\mathrm{Ob}-\mathrm{R}$ isoforms remain to be fully clarified, although $\mathrm{Ob}-\mathrm{Ra}$ is able to perform signal transduction and has been involved in leptin transport across the bloodbrain barrier, and $\mathrm{Ob}-\mathrm{Re}$ has been proposed as a soluble leptin-binding protein (Tartaglia et al. 1995, Murakami et al. 1997, Tartaglia 1997, Bjorbæk et al. 1998). Moreover, the contribution of short Ob-R variants to the modulation of the signal-transducing ability of the $\mathrm{Ob}-\mathrm{Rb}$ isoform has been suggested (White et al. 1997, White \& 
Tartaglia 1999). Thus, it is likely that the biological actions of leptin upon target tissues may depend, at least partially, on the balance of expression of different $\mathrm{Ob}-\mathrm{R}$ isoforms.

The present study was undertaken to provide new insights into the mode of action of leptin on rat adrenal. To this end, two experimental approaches were employed. First, the effects of the active leptin fragment, leptin 116-130 amide, on basal and adrenocorticotropin (ACTH)-stimulated corticosterone secretion in vitro were tested and compared with those of native leptin. Secondly, the pattern of adrenal expression and hormonal regulation of leptin receptor (Ob-R) mRNA isoforms was assessed by means of semi-quantitative RT-PCR. Results presented herein indicate that regulation of $\mathrm{Ob}-\mathrm{R}$ mRNA expression may represent a novel regulatory step whereby $\mathrm{ACTH}$ and leptin interact in the modulation of rat adrenal function.

\section{Materials and Methods}

\section{Animals and drugs}

Adult, 75-day-old Wistar male rats housed under constant conditions of light $(14 \mathrm{~h}$ of light; from $0700 \mathrm{~h})$ and temperature $\left(22^{\circ} \mathrm{C}\right)$ were used. Experimental procedures were approved by the Córdoba University Ethical Committee for animal experimentation and were conducted in accordance with the European Union normative for care and use of experimental animals.

Human recombinant leptin was produced in Saccharomyces cervisae as described elsewhere (Considine et al. 1996), and kindly donated by Eli Lilly (Indianapolis, IN, USA). Mouse leptin 116-130 amide was purchased from Bachem AG (Bubendorf, Switzerland). ACTH was obtained from Sigma (St Louis, MO, USA).

\section{Tissue incubations}

For static incubations, adrenal glands were bilaterally removed upon decapitation of experimental animals, dissected free of the surrounding fat, and cut into two pieces of approximately equal size (mean weight/piece: $22.9 \pm 0.375 \mathrm{mg} /$ piece, 2 slices/adrenal). Adrenal slices (4 slices/well) were incubated in $2 \mathrm{ml}$ Dulbecco's modified Eagle's medium (DMEM)/F12 medium (1:1; Life Technologies, Grand Island, NY, USA) supplemented with $0.1 \mathrm{~g} / 1$ gentamicin in a Dubnoff shaker $(60$ cycles/ $\min )$ at $37^{\circ} \mathrm{C}$ under an atmosphere of $5 \% \mathrm{CO}_{2}-95 \% \mathrm{O}_{2}$. After $60 \mathrm{~min}$ preincubation, the media were replaced either by fresh medium or medium containing increasing doses of leptin $116-130$ amide $\left(10^{-9}-10^{-5} \mathrm{M}\right)$. For comparative analysis, a group of adrenals was incubated in the presence of human recombinant leptin $\left(10^{-7} \mathrm{M}\right)$. In addition, to test the ability of leptin and leptin 116-130 amide to modulate stimulated corticosterone secretion, a similar experimental setting was carried out in the presence of ACTH $\left(10^{-7} \mathrm{M}\right)$. After 90 and $180 \mathrm{~min}$, $100-\mu l$ aliquots from the incubation media were taken for corticosterone measurements, as described below. Incubations were terminated at the latter time-point, when samples of adrenal tissue were frozen in liquid nitrogen and stored at $-70{ }^{\circ} \mathrm{C}$ until used for RNA analysis.

\section{Corticosterone measurements}

Corticosterone levels in tissue incubation media were measured using a commercial kit from ICN Biomedicals (Costa Mesa, CA, USA). The sensitivity of the assay was $2.5 \mathrm{ng} /$ tube, and the intra-assay coefficient of variation was $4 \cdot 5 \%$.

\section{$R N A$ analysis by semi-quantitative RT-PCR}

The pattern of expression and hormonal regulation of Ob-R subtype mRNAs in rat adrenal gland was assessed by semi-quantitative RT-PCR, using isoform-specific oligo-primer pairs. Total RNA was isolated from incubated adrenal samples using the single-step, acid guanidinium thiocyanate-phenol-chloroform extraction method (Chomczynski \& Sacchi 1987). Complementary DNA (cDNA) was prepared using $4 \mu \mathrm{g}$ total RNA and specific antisense primers (see below) in $30 \mu \mathrm{l}$ final volume, as described elsewhere (García et al. 2000, Tena-Sempere et al. 2000a). PCR amplification of cDNA samples was carried out using the following primer pairs: $\mathrm{Ob}-\mathrm{Ra}$ sense (5'-CCT ATC GAG AAA TAT CAG TTT A-3') and Ob-Ra antisense (5'-TCA AAG AGT GTC CGC TCT CT- $3^{\prime}$ ) for amplification of a 285-bp fragment of rat Ob-Ra isoform cDNA; Ob-Rb sense (5'-TGG CCC ATG AGT AAA GTG AAT-3') and Ob-Rb antisense (5'-CCA GAA GAA GAG GAC CAA ATA-3') for amplification of a 386-bp fragment of rat $\mathrm{Ob}-\mathrm{Rb}$ isoform cDNA; Ob-Rc sense (5'-ATT GTA CCG GTA ATT ATT TCC T- $3^{\prime}$ ) and Ob-Rc antisense (5'-CTG CAA CCT TAG ATA TCT TGG-3') for amplification of a 181-bp fragment of rat $\mathrm{Ob}-\mathrm{Rc}$ isoform cDNA; Ob-Re sense (5'-GCA GAA TCA GCA CAC ACT GTT-3') and Ob-Re antisense (5'-GTA AAA GCA CAG TAC ACA TAC C-3') for amplification of a 301-bp fragment of rat Ob-Re isoform cDNA; and Ob-Rf sense (5'-AGA GGA TAT ATA GTG GAT GCC G-3') and Ob-Rf antisense (5'-CAC AAA TGA GCC ATC TTC AAA CC-3') for amplification of a 411-bp fragment of rat $\mathrm{Ob}-\mathrm{R} f$ isoform $\mathrm{cDNA}$. To provide an appropriate internal control, coamplification of a 290-bp fragment of L19 ribosomal protein mRNA was carried out in each sample using the primer pair: L19-sense (5'-GAA ATC GCC AAT GCC AAC TC-3') and L19-antisense (5'-ACC TTC AGG TAC AGG CTG TG-3'). The reported sets of primers were selected based on previous references (García et al. 2000, Tena-Sempere et al. 2000a), and synthesized 


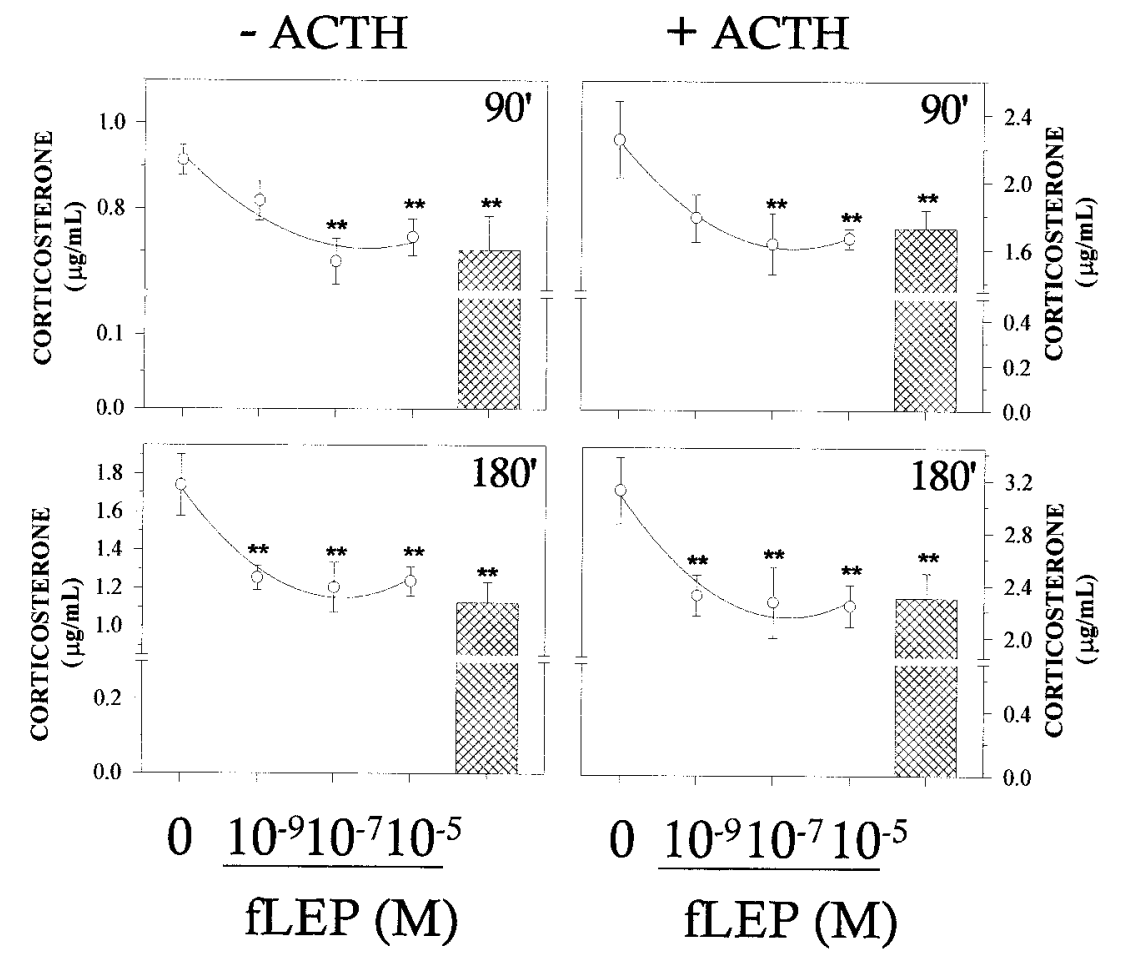

Figure 1 Inhibition of basal (left panels) and ACTH-stimulated (right panels) corticosterone secretion in vitro by an active fragment of the leptin molecule comprising amino acids 116-130 (fLEP). Such an inhibitory effect was similar in magnitude to that of human recombinant leptin (at $10^{-7} \mathrm{M}$; cross-hatched bars). The patterns of hormone release after 90 and $180 \mathrm{~min}$ incubation are presented. Values are given as means \pm S.E.M. $(n=8-10$ samples/group). ${ }^{* *} P<0 \cdot 01$ compared with corresponding controls (ANOVA followed by Tukey's test).

according to the published rat cDNA sequences of $\mathrm{Ob}-\mathrm{R}$ isoforms (Tartaglia et al. 1995, Lee et al. 1996, Takaya et al. 1996) and L19 ribosomal protein (Chang et al. 1987).

To enable appropriate amplification in the exponential phase for each target, PCR amplification of isoformspecific $\mathrm{Ob}-\mathrm{R}$ and $\mathrm{L} 19$ ribosomal protein transcripts was carried out in separate reactions with different numbers of cycles (see below), but using similar amounts of the corresponding cDNA templates generated in single RT reactions, as described elsewhere (Santana et al. 1996, Tena-Sempere et al. 2000a). PCR reactions consisted of a denaturing cycle at $97^{\circ} \mathrm{C}$ for $5 \mathrm{~min}$, followed by cycles of amplification defined by denaturation at $96^{\circ} \mathrm{C}$ for $1.5 \mathrm{~min}$, annealing at $55^{\circ} \mathrm{C}$ for $1.5 \mathrm{~min}$, and extension at $72{ }^{\circ} \mathrm{C}$ for $3 \mathrm{~min}$. A final extension cycle of $72{ }^{\circ} \mathrm{C}$ for 15 min was included. The number of cycles was optimized to ensure amplification in the exponential phase of PCR. Different numbers of cycles were tested for $\mathrm{Ob}-\mathrm{R}$ isoforms (ranging between 25 and 45) and L19 ribosomal protein (ranging between 14 and 30) and 33 and 20 cycles were chosen, respectively, for further analysis. In all assays, reactions without RT were included, yielding negative amplification (data not shown).
PCR-generated DNA fragments were resolved in Trisborate buffered $1.5 \%$ agarose gels, and visualized by ethidium bromide staining using a digital imaging system (Gelprinter Super software, TDI Ltd, Madrid, Spain), their molecular sizes being determined by comparison with size markers run together with the cDNA products (PCR 50-bp Step Ladder, Promega, Madison, WI, USA; DNA Molecular Weight Marker, Roche Diagnostics $\mathrm{GmbH}$, Mannheim, Germany). Specificity of PCR products was confirmed by Southern hybridization, using radiolabeled nested oligonucleotide primers and/or digestion with specific restriction enzymes (data not shown), as described elsewhere (García et al. 2000). For quantitative evaluation, absolute optical densities (OD) of RT-PCR signals were obtained by densitometric scanning using an image analysis system (1-D Manager, TDI Ltd). The values for the specific targets were normalized according to those of L19 ribosomal protein to express arbitrary units of relative abundance of the specific messages (i.e. relative expression). To ensure that equal inputs of RNA were added to RT-PCR reactions, only samples yielding roughly similar OD values for L19 bands were considered for further analysis. In addition, to minimize potential 


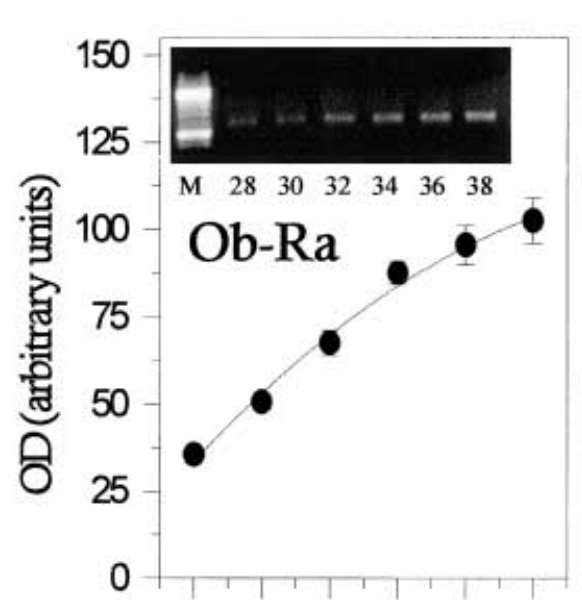

$\begin{array}{llllll}28 & 30 & 32 & 34 & 36 & 38\end{array}$

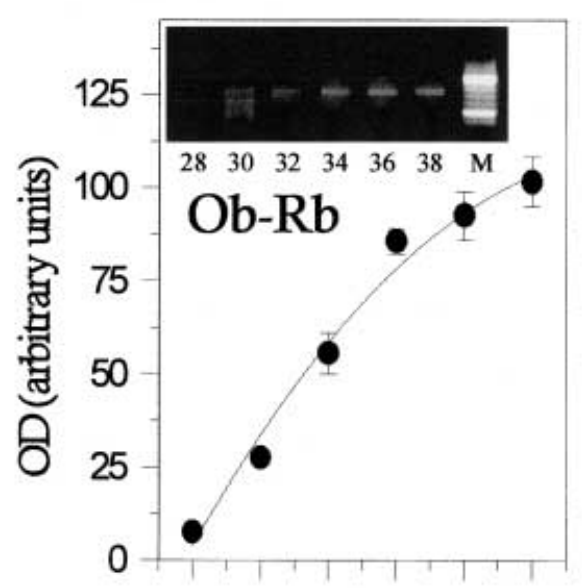

$\begin{array}{llllll}28 & 30 & 32 & 34 & 36 & 38\end{array}$

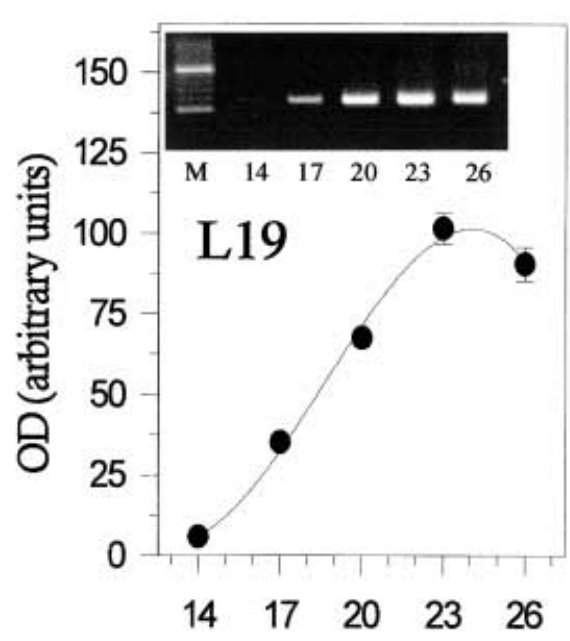

Cycles $\left(n^{\circ}\right)$
RT-PCR artifacts due to inherent reaction variability, all data points were repeated, for each target, at least three times using independent RNA samples.

\section{Presentation of data and statistics}

RT-PCR analyses were carried out in triplicate. When appropriate, semi-quantitative data are presented as means \pm s.E.M. from 3 independent observations. Tissue incubations were carried out in duplicate. Hormonal levels are expressed as normalized values per $100 \mathrm{mg}$ incubated tissue, and data are presented as means \pm s.E.M. $(n=8-10$ samples/group). Results were analyzed for statistically significant differences using ANOVA, followed by Tukey's test. $P<0 \cdot 05$ was considered significant.

\section{Results}

Effects of the active fragment of leptin, leptin 116-130 amide, on basal and ACTH-stimulated corticosterone secretion in vitro

A domain of the leptin molecule between amino acids 116 and 130 has been proven to be relevant in the leptinmediated regulation of food intake and luteinizing hormone (LH), prolactin (PRL) and testosterone secretion (Grasso et al. 1997, González et al. 1999, Tena-Sempere et al. 2000b). To evaluate the contribution of this area of the molecule to the effects of leptin on corticosterone secretion, adrenal slices were incubated in the presence of human recombinant leptin $\left(10^{-7} \mathrm{M}\right)$ or increasing concentrations of leptin 116-130 amide. Overall, a significant inhibition in both basal and ACTH-stimulated corticosterone release in vitro was observed after exposure to $10^{-9}-10^{-5} \mathrm{M}$ leptin fragment. Subtle differences, however, were noticed in the time-course response to the lower dose of the active fragment of leptin, as $10^{-9} \mathrm{M}$ leptin 116-130 amide significantly inhibited basal and ACTH-stimulated corticosterone secretion only after 180 min incubation. On the other hand, $10^{-7}-10^{-5} \mathrm{M}$ doses of leptin fragment significantly reduced corticosterone secretion at both time-points tested (90 and

Figure 2 Optimization of RT-PCR conditions for semi-quantitative determination of Ob-Ra, Ob-Rb and L19 ribosomal protein mRNAs. For amplification in the exponential phase of PCR, different numbers of cycles were tested for each message. Quantitative analysis of the cycle-dependency for the generated PCR signals revealed a strong linear relationship between cycles 28 and 38 in the case of Ob-Ra (correlation coefficient $\left.r^{2}=0.9913\right)$ and Ob-Rb $\left(r^{2}=0.9842\right)$, and between cycles 14 and 23 in the case of L19 ribosomal protein $\left(r^{2}=0.9989\right)$. Optimization of RT-PCR conditions was carried out using total RNA from control, 75-day-old rat adrenal. Values are given as means \pm S.D. of two independent determinations. A representative ethidium bromide-stained gel electrophoresis of the DNA products generated for each target (Ob-Ra, Ob-Rb and L19 ribosomal protein) is presented in the insets. 

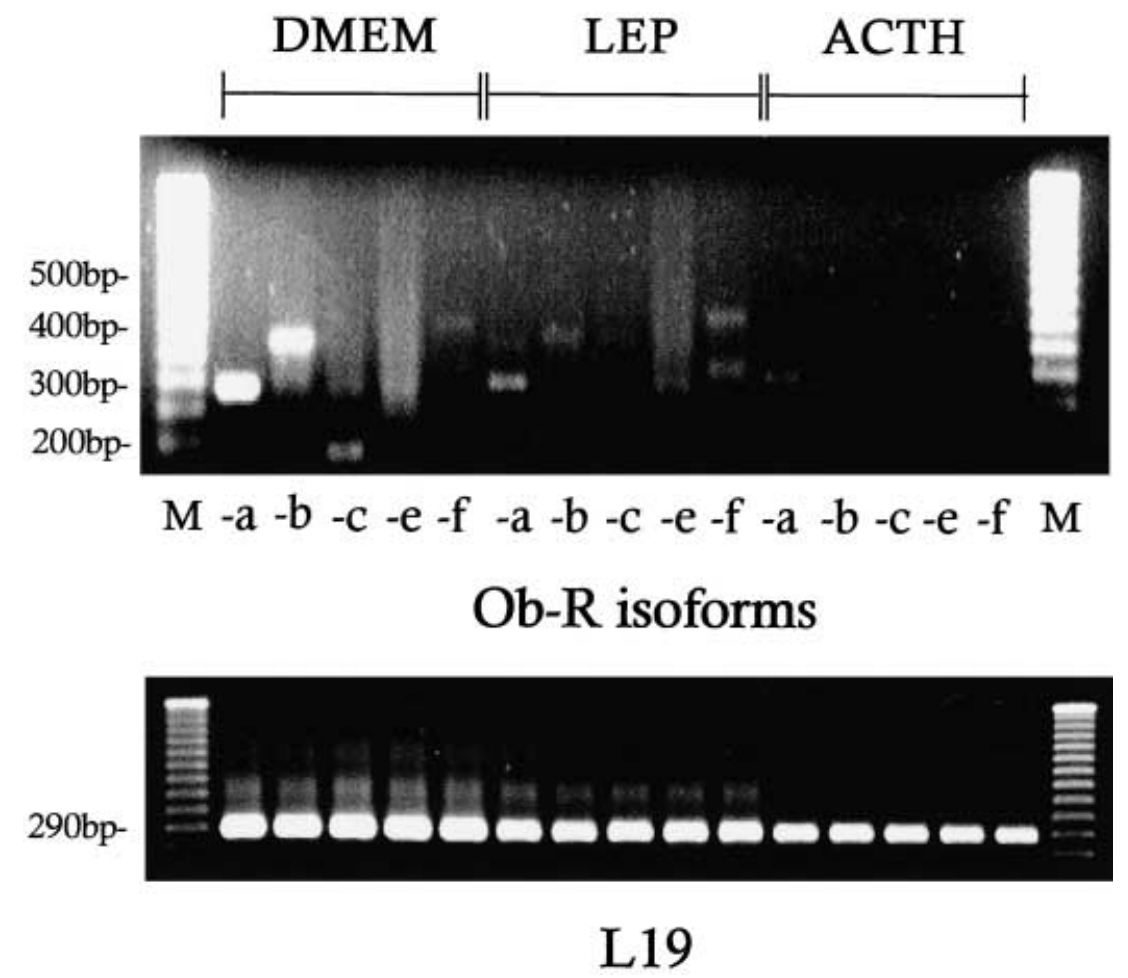

Figure 3 Pattern of expression of mRNAs encoding Ob-Ra, Ob-Rb, Ob-Rc, Ob-Re and Ob-Rf isoforms in rat adrenal. In addition to basal (DMEM) conditions, isoform-specific expression levels were assessed after stimulation with homologous (leptin: LEP; $10^{-7} \mathrm{M}$ ) and heterologous $\left(\mathrm{ACTH} ; 10^{-7} \mathrm{M}\right.$ ) signals. Clear-cut down-regulation of the different $\mathrm{Ob}-\mathrm{R}$ isoform messages was observed. A representative ethidium bromide-stained gel (out of triplicates) of target products is presented, as well as amplification signals for L19 (internal control). The sizes of the generated products were calculated by comparison with mobility of a 50 bp DNA step ladder, the bp length of representative markers being indicated on the left.

$180 \mathrm{~min})$. Likewise, recombinant leptin decreased, to a similar extent, basal and stimulated corticosterone secretion by incubated adrenal tissue (Fig. 1).

\section{Optimization of semi-quantitative RT-PCR assays}

RT-PCR assays were optimized for semi-quantitative analysis of $\mathrm{Ob}-\mathrm{R}$ isoform and L19 ribosomal protein mRNA expression. To obtain optimal conditions for amplification, i.e. in the exponential phase of PCR, different numbers of PCR cycles were tested for each message. Considering that preliminary assays demonstrated that $\mathrm{Ob}-\mathrm{Ra}$ and $\mathrm{Ob}-\mathrm{Rb}$ are the most abundant isoforms in rat adrenal, this procedure was carried out in detail for the $\mathrm{Ob}-\mathrm{Ra}$ and $\mathrm{Ob}-\mathrm{Rb}$ variants, as well as for the L19 transcript. As shown in Fig. 2, plotting intensity of PCR signals (as expressed by absolute OD values) against the number of amplification cycles revealed a strong linear relationship between cycles 28 and 38 in the case of Ob-Ra (correlation coefficient $r^{2}=0.9913$ ) and Ob-Rb $\left(r^{2}=0.9842\right)$, and between cycles 14 and 23 in the case of
L19 ribosomal protein $\left(r^{2}=0 \cdot 9989\right)$. Thus, PCR amplification of Ob-R-related and L19 ribosomal protein transcripts was carried out in separate reactions using 33 and 20 amplification cycles respectively.

Expression and hormonal regulation of $O b-R m R N A$ isoforms in rat adrenal

RT-PCR analysis using isoform-specific primers revealed predominant expression of $\mathrm{Ob}-\mathrm{Ra}$ and $\mathrm{Ob}-\mathrm{Rb}$ mRNAs in rat adrenal. In addition, moderate expression levels for $\mathrm{Ob}-\mathrm{Rc}$ and $\mathrm{Ob}-\mathrm{Rf}$ variants were detected, whereas negligible signals were observed for Ob-Re (Fig. 3). This pattern of isoform expression appeared to be under hormonal regulation. Exposure to recombinant leptin $\left(10^{-7} \mathrm{M}\right)$ or ACTH $\left(10^{-7} \mathrm{M}\right)$ for $180 \mathrm{~min}$ induced a clear-cut down-regulation of Ob-R isoform mRNAs. However, subtle differences were detected in the magnitude of such a response between isoforms. Specifically, among those with predominant expression levels (i.e. $\mathrm{Ob}-\mathrm{Ra}$ and $\mathrm{Ob}-\mathrm{Rb}$ ), a higher degree of suppression was 
$\mathrm{Ob}-\mathrm{Ra}$

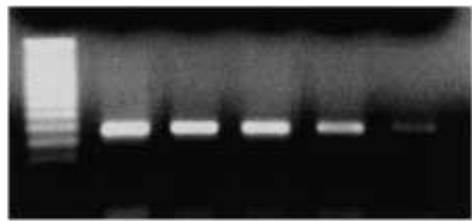

$-285 \mathrm{bp}$

\author{
$\mathrm{Ob}-\mathrm{Rb}$
}

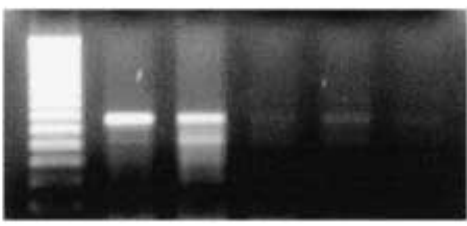

$-386 b p$

L19

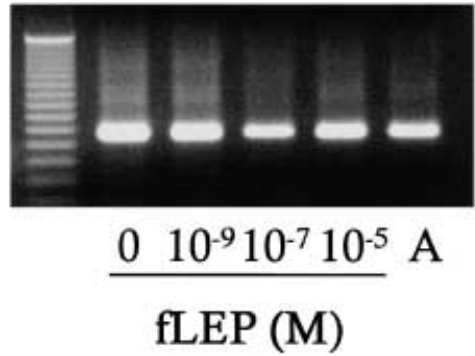

Figure 4 Ligand-induced down-regulation of mRNAs encoding $\mathrm{Ob}-\mathrm{Ra}$ and $\mathrm{Ob}-\mathrm{Rb}$ isoforms. Exposure to increasing concentrations of leptin 116-130 amide (fLEP) resulted in a dose-dependent reduction in the mRNA expression levels of both isoforms in rat adrenal. For comparison, the effect of ACTH $\left(10^{-7} \mathrm{M}\right.$; A) on $\mathrm{Ob}-\mathrm{Ra}$ and $\mathrm{Ob}-\mathrm{Rb}$ messages was evaluated in the same assays. Representative ethidium bromide-stained gels (out of triplicates) of target products are presented, as well as amplification signals for L19 in the same samples (internal control). The sizes of the generated products were calculated by comparison with the mobility of a 50 bp DNA step ladder, and are indicated on the right.

observed for the Ob-Rb subtype (Fig. 3). Ligand-induced down-regulation of $\mathrm{Ob}-\mathrm{R}$ mRNA expression was further confirmed by challenge of adrenal tissue with increasing doses $\left(10^{-9}-10^{-5} \mathrm{M}\right)$ of leptin 116-130 amide (Fig. 4). In this experimental setting, a dose-dependent decrease in relative levels of $\mathrm{Ob}-\mathrm{Ra}$ and $\mathrm{Ob}-\mathrm{Rb}$ isoform expression was detected, the response being elicited by lower concentrations of the active fragment in the case of $\mathrm{Ob}-\mathrm{Rb}$ $\left(10^{-9} \mathrm{M}\right)$ compared with Ob-Ra $\left(10^{-5} \mathrm{M}\right)$. A compilation of semi-quantitative data on the relative expression levels of $\mathrm{Ob}-\mathrm{Ra}$ and $\mathrm{Ob}-\mathrm{Rb}$ mRNAs in rat adrenal after exposure to increasing doses of the active leptin fragment, leptin 116-130 amide $\left(10^{-9}-10^{-5} \mathrm{M}\right)$, or ACTH $\left(10^{-7}\right.$ $\mathrm{M})$ is presented in Fig. 5.

\section{Discussion}

The mechanisms whereby leptin regulates the HPA axis are multifaceted and are likely to involve central and peripheral actions (Casanueva \& Dieguez 1999). Among different experimental approaches used to delineate the
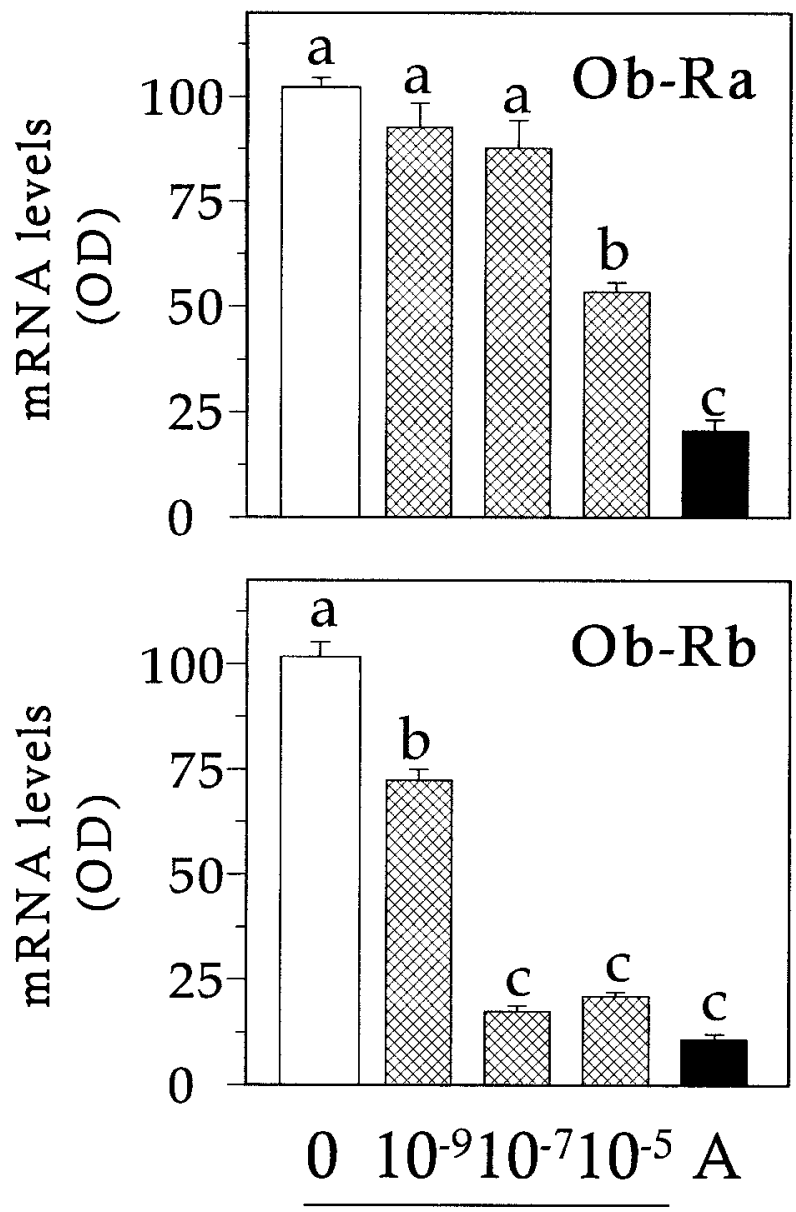

\section{fLEP (M)}

Figure 5 Compilation of semi-quantitative data on the steady-state levels of Ob-Ra and Ob-Rb mRNAs in adrenal tissue incubated in the presence of increasing concentrations of leptin 116-130 amide $\left(10^{-9}\right.$ to $10^{-5} \mathrm{M}$; fLEP) or ACTH $\left(10^{-7} \mathrm{M}\right.$; A). Relative levels of expression were obtained in each sample by normalization of absolute optical densities (OD) of each target (Ob-Ra and Ob-Rb) to that of L19 signal, thus expressing arbitrary units of relative abundance of the specific messages. Data with different superscript letters are significantly different $(P<0 \cdot 01$; ANOVA followed by Tukey's test).

effects and mode of action of leptin in different target tissues, testing of the biological actions of several synthetic peptides generated to replicate restricted areas of the leptin protein has been used. Interestingly, it was shown recently that a fragment of the murine leptin protein comprising amino acids 116 to 130 (termed leptin 116-130 amide) displayed actions similar to those of the native molecule in terms of food intake and body weight gain in female $o b / o b$ mice (Grasso et al. 1997), elicited LH and PRL secretion in fasted adult male rats (González et al. 1999), and 
mimicked the ability of leptin to inhibit testosterone secretion in vitro (Tena-Sempere et al. 2000b). Present results confirm the inhibitory role of leptin in the regulation of corticosterone secretion at the adrenal level (Bornstein et al. 1997, Pralong et al. 1998), and map such an effect, at least partially, to its 116-130 amino acid domain. Moreover, from the standpoint of a structurefunction relationship, our data reinforce the functional relevance of this area of the leptin molecule, and suggest a key role for this domain in ligand-receptor binding and/or activation. However, a conspicuous lack of interaction between the $\mathrm{Ob}-\mathrm{Rb}$ subtype and this leptin fragment has been reported very recently (Grasso et al. 1999), thus opening up the possibility that the observed effects may be due to interaction with other $\mathrm{Ob}-\mathrm{R}$ isoforms or as yet undefined leptin-signaling pathways.

The events involved in the modulation of the biological actions of leptin in target tissues include regulation of $\mathrm{Ob}-\mathrm{R}$ expression. However, despite the role of leptin in the control of adrenal function, detailed characterization of the pattern of $\mathrm{Ob}-\mathrm{R}$ isoform expression as well as its potential regulation by key signals in adrenal hormonal control are still pending. Our current data provide evidence of a complex pattern of alternative splicing of the $\mathrm{Ob}-\mathrm{R}$ gene in rat adrenal gland; this results in the predominant expression of $\mathrm{Ob}-\mathrm{Ra}$ and $\mathrm{Ob}-\mathrm{Rb}$ mRNAs and moderate expression levels for $\mathrm{Ob}-\mathrm{Rc}$ and $\mathrm{Ob}-\mathrm{Rf}$ variants, whereas negligible signals are observed for $\mathrm{Ob}-\mathrm{Re}$. Identification of the cellular distribution of $\mathrm{Ob}-\mathrm{R}$ isoforms within rat adrenal is still pending. However, novel data on expression levels of mRNAs encoding different $\mathrm{Ob}-\mathrm{R}$ subtypes is relevant considering the divergent functional capacities of different Ob-R subtypes (Tartaglia et al. 1995, Lee et al. 1996, Takaya et al. 1996, Murakami et al. 1997, Tartaglia 1997, Bjorbæk et al. 1998, White \& Tartaglia 1999), as well as the proposed interaction between $\mathrm{Ob}-\mathrm{R}$ isoforms in signaling the biological effects of leptin (White et al. 1997, White \& Tartaglia 1999, Garcia et al. 2000).

To our knowledge, this is the first report to demonstrate down-regulation of Ob-R mRNA expression by its cognate ligand. Indeed, the general mechanisms whereby leptin desensitizes its own response are only partially understood, although the contribution of ligand-induced decrease in the number of cell-surface $\mathrm{Ob}-\mathrm{Rs}$ has been proposed very recently (Barr et al. 1999, Uotani et al. 1999). Our current data strongly suggest that, in addition, homologous down-regulation of $\mathrm{Ob}-\mathrm{R}$ may involve an actual decrease in the expression levels of Ob-R mRNA, a mechanism proposed for desensitization of other receptor systems (for example see Tena-Sempere \& Huhtaniemi 1999). In this context, it becomes relevant to correlate the reported decrease in Ob-R isoform mRNA expression following exposure to native leptin or its active fragment with changes in the biological effects of leptin or Ob-R expression at the protein level to evaluate fully the physiological relevance of this regulatory event. Interestingly, homologous down-regulation of $\mathrm{Ob}-\mathrm{R}$ mRNA involved decreased expression of different isoform messages, in line with previous studies in terms of the number of cell-surface Ob-R subtypes (Barr et al. 1999, Uotani et al. 1999). However, subtle differences were detected in the magnitude of response to $10^{-7} \mathrm{M}$ leptin between isoforms. This was confirmed for $\mathrm{Ob}-\mathrm{Ra}$ and $\mathrm{Ob}-\mathrm{Rb}$ after stimulation with increasing concentrations of leptin 116130 amide. This analysis revealed that homologous downregulation appears in a different range of doses for $\mathrm{Ob}-\mathrm{Ra}$ and $\mathrm{Ob}-\mathrm{Rb}$ isoforms, the sensitivity being higher for the latter. Whether this phenomenon is relevant in the autolimitation of leptin action upon rat adrenal remains to be elucidated. However, the fact that leptin amide was able to inhibit adrenal corticosterone release and to decrease $\mathrm{Ob}-\mathrm{Rb}$ mRNA expression in a similar range of doses makes it tempting to propose such a possibility.

Potential modulation of expression levels of isoformspecific Ob-R mRNAs by ACTH, i.e. a pivotal factor in adrenal physiology, was explored. Our analysis demonstrated that, in addition to its cognate ligand, Ob-R mRNA expression is under the control of heterologous signals. Interestingly, a similar phenomenon has been observed by our group in rat testis, where leptin inhibits testosterone secretion (Tena-Sempere et al. 1999, 2000b), and $\mathrm{Ob}-\mathrm{R}$ mRNA expression is down-regulated by heterologous (human choriogonadotropin) as well as homologous factors (M Tena-Sempere and E Aguilar, unpublished observations). Thus, it is tempting to suggest that leptin-induced inhibition of corticosterone secretion may be limited, at least partially, by down-regulation of $\mathrm{Ob}-\mathrm{R}$ gene expression by leptin itself and ACTH, the major corticosterone elicitor. An analogous model may apply also to other steroidogenic tissues.

In conclusion, based on our present data, it is proposed that control of $\mathrm{Ob}-\mathrm{R}$ mRNA expression may represent a novel regulatory step whereby ACTH and leptin interact in the modulation of rat adrenal function.

\section{Acknowledgements}

The authors are indebted to Rocío Campón and Inmaculada Aguilar for their excellent technical assistance. M T-S is indebted to Dr I Huhtaniemi for helpful discussions during the design and preparation of this manuscript. This work was supported by grants from DGESIC (Ministerio de Educación y Cultura, Spain) and project 1FD97-0696-02 (FEDER).

\section{References}

Barr VA, Lane K \& Taylor SI 1999 Subcellular localization and internalization of the four human leptin receptor isoforms. Journal of Biological Chemistry 274 21416-21424. 
Bjorbæk C, Elmquist JK, Michl P, Ahima RS, van Bueren A, McCall AL \& Flier JS 1998 Expression of leptin receptor isoforms in rat brain microvessels. Endocrinology 139 3485-3491.

Bornstein SR, Uhlmann K, Haidan A, Ehrhart-Bornstein \& Scherbaum WA 1997 Evidence for a novel peripheral action of leptin as a metabolic signal to the adrenal gland: leptin inhibits cortisol release directly. Diabetes 46 1235-1238.

Casanueva FF \& Dieguez C 1999 Neuroendocrine regulation and actions of leptin. Frontiers in Neuroendocrinology 20 317-363.

Chang X-L, Lin A, McNally J, Pelleg D, Meyuhas O \& Wool Y 1987 The primary structure of rat ribosomal protein L19. Journal of Biological Chemistry 262 1111-1115.

Chomczynski P \& Sacchi N 1987 Single-step method of RNA isolation by acid guanidinium thiocyanate-phenol-chloroform extraction. Analytical Biochemistry 162 156-159.

Considine RV, Sinha MK, Heiman ML, Kriauciunas A, Stephens TW, Nyce MR, Ohanneisian JP, Marco CC, McKee LJ, Bauer TL \& Caro JF 1996 Serum immunoreactive leptin concentrations in normal-weight and obese humans. New England Journal of Medicine $334292-295$.

Friedman JM \& Halaas JL 1998 Leptin and regulation of body weight in mammals. Nature 395 763-770.

García MD, Casanueva FF, Dieguez C \& Señaris RM 2000 Gestational profile of leptin messenger ribonucleic acid (mRNA) content in the placenta and adipose tissue in the rat, and regulation of the mRNA levels of the leptin receptor subtypes in the hypothalamus during pregnancy and lactation. Biology of Reproduction 62 698-703.

González LC, Pinilla L, Tena-Sempere M \& Aguilar E 1999 Leptin $_{116-130}$ stimulates prolactin and LH secretion in fasted adult male rats. Neuroendocrinology 70 213-220.

Grasso P, Leinung MC, Ingher SP \& Lee DW 1997 In vivo effects of leptin-related synthetic peptides on body weight and food intake in female $o b / o b$ mice: localization of leptin activity to domains between amino acid residues 106-140. Endocrinology 138 1413-1418.

Grasso P, White DW, Tartaglia LA, Leinung MC \& Lee DW 1999 Inhibitory effects of leptin-related synthetic peptide $116-130$ on food intake and body weight gain in female C57BL/6J ob/ob mice may not be mediated by peptide activation of the long isoform of the leptin receptor. Diabetes 48 2204-2209.

Lee G, Proenca R, Montez JM, Carrol KM, Darvishzadeh JG, Lee JI \& Friedman JM 1996 Abnormal splicing of leptin receptor in diabetic mice. Nature 379 632-635.

Malendowicz LK, Nussdorfer GG \& Markowska A 1997 Effects of recombinant murine leptin on steroid secretion of dispersed rat adrenocortical cells. Journal of Steroid Biochemistry and Molecular Biology 63 123-125.

Murakami T, Yamashita T, Iida M, Kuwajima M \& Shima K 1997 A short form of leptin receptor performs signal transduction. Journal of Biological Chemistry 231 26-29.

Pralong FP, Roduit R, Waeber G, Castillo E, Mosimann F, Thorens B \& Galliard RC 1998 Leptin inhibits directly glucocorticoid secretion by normal human and rat adrenal gland. Endocrinology 139 4264-4268.

Rosenbaum M \& Liebel RL 1998 Leptin: a molecule integrating somatic energy stores, energy expenditure and fertility. Trends in Endocrinology and Metabolism 9 117-123.
Santana P, Llanes L, Hernández Y, González-Robayna Y, Tabraue C, González-Reyes J, Quintana J, Estévez F, Ruiz de Galarreta CM \& Fanjul LF 1996 Interleukin-1 $\beta$ stimulates sphingomyelin hydrolysis in cultured granulosa cells: evidence for a regulatory role of ceramide on progesterone and prostaglandin biosynthesis. Endocrinology 137 2480-2489.

Takaya K, Ogawa Y, Isse N, Okazaki T, Satoh N, Masuzaki H, Mori K, Tamura N, Hosoda K \& Nakao K 1996 Molecular cloning of rat leptin receptor isoform complementary DNAs: identification of a missense mutation in Zucker fatty $(\mathrm{fa} / \mathrm{fa})$ rats. Biochemical and Biophysical Research Communications 225 75-83.

Tartaglia LA 1997 The leptin receptor. Journal of Biological Chemistry 272 6093-6096.

Tartaglia LA, Dembski M, Weng X, Deng N, Culpepper J, Devos R, Richards GJ, Campfield LA, Clark FT, Deeds J, Muir C, Sanker S, Moriarty A, Moore KJ, Smutko JS, Mays GG, Woolf EA \& Tepper RI 1995 Identification and expression cloning of a leptin receptor, OB-R. Cell 83 1263-1272.

Tena-Sempere M \& Huhtaniemi I 1999 Gonadotropin receptors. In Molecular Biology in Reproductive Medicine, pp 165-200. Eds BCJM Fauser, AJ Rutherford, JF Strauss \& A van Steirteghem. New York: Parthenon Publishing.

Tena-Sempere M, Pinilla L, González LC, Dieguez C, Casanueva FF \& Aguilar E 1999 Leptin inhibits testosterone secretion from adult rat testis in vitro. Journal of Endocrinology 161 211-218.

Tena-Sempere M, Navarro J, Pinilla L, González LC, Huhtaniemi I \& Aguilar E 2000a Neonatal exposure to estrogen differentially alters estrogen receptor $\alpha$ and $\beta$ messenger ribonucleic acid expression in rat testis during postnatal development. Journal of Endocrinology 165 345-357.

Tena-Sempere M, Pinilla L, González LC, Navarro J, Dieguez C, Casanueva FF \& Aguilar E 2000 b In vitro pituitary and testicular effects of leptin-related synthetic peptide, leptin ${ }_{116-130}$ amide, involve actions both similar to and distinct from those of the native leptin molecule in the adult rat. European Journal of Endocrinology 142 406-410.

Uotani S, Bjorbaek C, Tornoe J \& Flier JS 1999 Functional properties of leptin receptor isoforms: internalization and degradation of leptin and ligand-induced receptor down-regulation. Diabetes $\mathbf{4 8}$ 279-286.

White DW \& Tartaglia LA 1999 Evidence for ligand-independent homo-oligomerization of leptin receptor (OB-R) isoforms: a proposed mechanism permitting productive long-form signaling in the presence of excess short-form expression. Journal of Cell Biochemistry 73 278-288.

White DW, Kuropatwinski KK, Devos R, Baumann H \& Tartaglia LA 1997 Leptin receptor (OB-R) signaling. Cytoplasmic domain mutational analysis and evidence for receptor homo-oligomerization. Journal of Biological Chemistry 272 4065-4071.

Received 12 June 2000

Revised manuscript received 27 July 2000

Accepted 8 August 2000 